\title{
Chaucerove metafore u prijevodu Luke Paljetka. Kognitivna studija
}

\section{Abstract: Chaucer's Metaphors in Luko Paljetak's Translation: A Cognitive Study}

This article aims to identify conceptual metaphors in the Middle English text of The Miller's Prologue and The Miller's Tale and to find their equivalents in the Croatian translation done by Luko Paljetak, in order to deduce which metaphors are conventional in both languages and cultures. The investigation of conventionality will be based on the comparison of source concepts in English and Croatian linguistic expressions used in conceiving of metaphorical targets. Metaphors in both languages will be classified according to their cognitive function into structural, ontological, and orientational, which will appoint to the type(s) of metaphors with the greatest and smallest amount of overlapping. Finally, the analysis will lead to the conclusion whether the differences in metaphor usage in two languages are the consequence of cognitive differences between their speakers or the consequence of socio-cultural development that took place in the period of about 600 years which have passed between the original text and its translation. In general, the article should contribute to cognitive linguistics from a diachronic perspective.

Keywords: Lakoff and Johnson, cognitive conceptual theory of metaphor, conventional metaphors, structural, ontological and orientational metaphors, poetic metaphors, diachronic approach

\section{Uvod}

Canterburyjske priče najbolje su djelo Geoffreya Chaucera (1343./44.? - 1400.) i, po ocjeni stručnjaka, najbolje djelo napisano na srednjoengleskom jeziku. Ono donosi priče grupe hodočasnika koji su jednog travanjskog dana krenuli iz Southwarka, nedaleko Londona, u 
canterburyjsku katedralu na grob mučenika Thomasa Becketa. Pričama su se htjeli zabaviti na napornom četverodnevnom putovanju. Svaki hodočasnik trebao je ispričati dvije priče na putu do Canterburyja te dvije na povratku, a pripovjedač najbolje bio bi nagrađen po povratku u Southwark. Budući da je bilo trideset hodočasnika, Chaucer je trebao napisati 120 priča, međutim, iz nekog je razloga napisao samo 24 , od kojih je jedna Mlinareva. Ona pripada žanru komične priče koja se u europskoj književnosti obično naziva francuskim terminom fabliaux jer je tijekom srednjeg vijeka bila osobito popularna u Francuskoj (ali i u Italiji i drugdje), a u engleskoj je književnosti prije Chaucera gotovo nezabilježena. S obzirom na to da su joj glavni likovi bili stereotipni pripadnici srednje klase, čiji je govor obično bio jednostavan, a vrlo često i prostački, u engleskoj terminologiji naziva se i churl's tale. Tema priče tipično je bila nekakva gruba šala ili prevara, a gradila se na zapletu događaja u kojima su pojedini likovi dovedeni u zabludu (odatle i naziv comedy of errors) te u svojoj gluposti bivaju prevareni i izrugani. U Mlinarevoj priči nalazimo likove raspoređene u dva trokuta. Jedan čini: stari stolar John, njegova mlada i lijepa supruga Alisoun te njihov podstanar spretni student Nicholas; a drugi: Alisoun, Nicholas i narcisoidni crkvenjak Absolon. I Nicholas i Absolon udvaraju se Alisoun, ali osvaja je Nicholas, koji lukavo uspijeva nadmudriti i Johna i Absolona, da bi na kraju i sam djelomično postao žrtvom vlastite prevare. Priči prethodi jednako zabavan Proslov, koji donosi prepirku Krčmara i Mlinara o tome tko bi od hodočasnika trebao nastaviti niz započet romantičnom Vitezovom pričom. Mlinar se uspijeva grubo i razmetljivo nametnuti bez obzira na negodovanje Krčmara te odmah daje naslutiti da će njegova priča biti prostačka.

I Mlinareva priča i Mlinarev proslov obiluju metaforama te su upravo one predmet ove studije u kojoj ih analiziramo iz perspektive Lakoffove i Johnsonove kognitivno-konceptualne teorije, objavljene 1980. u Metaphors We Live By. Od tada do danas pojavili su se i novi, prilično raznoliki pristupi metafori, koji su se razlikovali ponajviše po tome što su polazili od različitih paradigmi metafora, pa su se književni kritičari i retoričari bavili novim, maštovitim i pjesničkim metaforama, dok su se (kognitivni) lingvisti i filozofi jezika bavili konvencionalnim metaforama. Kako tvrdi Chana Kronfeld, središnji problem s kojim se suočila teorija metafore bio je metodološke prirode (81). Svaka znanstvena disciplina postavljala je drugačija pitanja o metafori, zavisno od svog interesa, ne vodeći dovoljno računa o tome koliko su ona bila zanimljiva i adekvatna za paradigme metafora 
koje su bile u fokusu znanstvenika drugih disciplina. Koliki je bio raspon interesa za metaforu u to vrijeme pokazuju članci objavljeni u Metaphor and Thought (1993.), gdje su se u raspravu o metafori uključili i stručnjaci iz područja kognitivne i kliničke psihologije, obrazovanja i umjetne inteligencije. Krajem 20. st. te u posljednjih dvadeset godina i u samoj su se lingvistici pojavili novi pristupi metafori, kao što je npr. diskursni pristup, koji stavlja naglasak na jezični aspekt metafora, tj. na njihovu komunikaciju u dijaloškom kontekstu. Tako npr. Kövecs (2015.) zagovara tzv. kontekstualni pristup, a Gerard Steen (2008.) trodimenzionalni, u kojem metafora egzistira na tri razine: jezičnoj, konceptualnoj i komunikacijskoj. Dok je kognitivno-konceptualnoj teoriji metafore više svojstven globalan pogled na metaforu koji se temelji na zajedničkom tjelesnom iskustvu svih ljudi u poimanju svijeta, diskursni pristup uz globalnu perspektivu uključuje i lokalnu, tj. interakciju među ljudima u određenoj društvenoj situaciji. I sam Lakoff u međuvremenu je objavio novu teoriju metafore u The Neural Theory of Metaphor (2008.), u kojoj nastanak i razumijevanje konceptualnih metafora povezuje s neuralnom teorijom jezika, odnosno procesima u neuronskim mrežama mozga. Međutim, kako sam tvrdi, osnovne postavke kognitivne teorije objavljene u Metaphors We Live By ostale su jednako valjane kao što su bile i osamdesetih godina. S obzirom na predmet $\mathrm{i}$ ciljeve ovog rada, mi smo se u analizi metafora odlučili za klasičan kognitivni pristup koji konceptualizaciju stavlja u prvi plan, a njezinu jezičnu realizaciju i kontekstualizaciju u drugi.

U predgovoru knjige Metaphors We Live By George Lakoff i Mark Johnson ističu kako se njihova kognitivno-konceptualna teorija metafore uvelike razlikuje od tradicionalne, koja je u sedamdesetim godinama 20. st. još uvijek dominirala u filozofiji i lingvistici na zapadu (ix). Tradicionalnom teorijom smatraju teoriju metafore koja se temeljila na sličnosti dvaju predmeta (the comparison theory of metaphor), a koja potječe još od Aristotela i njegove Retorike. Stoljećima nakon antike metafora za filozofe i književnike bila je tek osnova slikovitog i poetskog izražavanja te joj nitko nije pridavao ikakvu ulogu u razumijevanju svijeta. (S obzirom na to da je od objavljivanja Lakoffove i Johnsonove kognitivno-konceptualne teorije prošlo četrdeset godina, gotovo da se može reći kako je i ona već tradicionalna.)

Ukratko, po tradicionalnoj teoriji metafora je lingvistički fenomen i upotrebljava se u književne i retoričke svrhe; temelji se na sličnosti dva predmeta koji se uspoređuju; nastaje svjesnom i namjernom upotrebom riječi te je potreban talent za njezino razumijevanje i stvaranje; kao govorna 
figura nije neophodna u svakidašnjoj ljudskoj komunikaciji. Nasuprot ovome Lakoff i Johnson dokazuju sljedeće: metafora pripada pojmovnoj, a ne samo jezičnoj domeni; njezina funkcija jest bolje razumijevanje nekih pojmova, a ne stvaranje umjetničkog ili estetskog dojma; često se ne temelji na sličnosti između dva predmeta, već na ljudskom iskustvu i znanju; upotrebljava se u svakidašnjem govoru bez ikakvog napora. Drugim riječima, metafora je neizbježna u procesu ljudskog razmišljanja i zaključivanja.

Lakoff i Johnson u metafori uočavaju dvije razine, metaforički koncept i metaforički lingvistički izraz. Metaforički koncept jest poimanje jednog pojmovnog područja, tj. cilja (target domain), uz pomoć drugog pojmovnog područja, tzv. izvora (source domain), dok je metaforički lingvistički izraz tek skup riječi iz jezične terminologije kojim se izražava taj koncept. Kada je metaforički jezični izraz uobičajen dio svakodnevnog govora, utemeljen na osnovnom konceptu koji konstantno koristimo u razmišljanju o svijetu i sebi samima, smatra se konvencionalnim, jer je „utvrđen konvencijom" (Lakoff i Johnson 54). Budući da je jedna od bitnih osobina jezika kreativnost i inovacija, jedan te isti metaforički koncept može se izraziti na više načina, odnosno s više metaforičkih lingvističkih izraza koji nisu uvijek konvencionalni.

Prema kognitivnoj funkciji, Lakoff i Johnson razlikuju tri osnovne vrste metafora. Strukturne metafore one su u kojima se struktura jednog pojma razumije uz pomoć strukture drugog pojma, odnosno u kojima se skup elemenata ciljnog pojma shvaća uz pomoć korespondentnih elemenata izvornog pojma. Ontološke metafore koriste se u poimanju biti prvenstveno apstraktnih predmeta koji se zbog svoje teško opisive prirode doživljavaju kao materijalni predmeti ili živa bića. Tako se npr. različite ideje, emocije, stanja i aktivnosti poimaju kao materijalni sadržaj koji se stavlja u spremnik ili pak kao sam spremnik, ili se pojavama i predmetima pridaju osobine živih bića. Orijentacijske metafore one su koje nastaju na temelju ljudske orijentacije u fizičkom prostoru te koriste izraze kao što su unutra - van, gore - dolje, naprijed - nazad i sl. Za sve tipove spomenutih konceptualnih metafora tipično je da se temelje na ljudskom iskustvu življenja u fizičkom svijetu, odnosno na postojećim, objektivnim sličnostima u doživljaju različitih apstraktnih pojmova i događaja s materijalnim, no budući da postoje i razlike u iskustvenim događajima, metafore mogu uključivati i različite vrste neobjektivne sličnosti. Na taj način nastaju kreativne ili inovativne metafore, koje ovise o osobnom razumijevanju jedne vrste iskustva kroz drugo i o mašti pojedinca. 
U Metaphors We Live By Lakoff i Johnson prvenstveno su se bavili metaforom u okviru zapadne kulture i engleskog govornog područja, dok su neznatnu pažnju posvećivali upotrebi metafora u drugim jezicima i kulturama. Međutim, već su sredinom 20. st. Whorfova i Sapirova istraživanja pokazala da jezična struktura oblikuje način na koji razmišljamo o svijetu i njihova je teorija općenito prihvaćena u lingvistici u relativnom smislu. Drugim riječima, jezik dokazano utječe na poimanje stvari u određenoj mjeri. Ako jezik determinira misao, opravdano je pretpostaviti da jezične razlike utječu i na metaforičku konceptualizaciju, odnosno na način kako je izražavamo. S obzirom na to da je jezik sastavni dio kulture, može se reći i da su metafore velikim dijelom određene i kulturom u okviru koje su nastale. Stoga prevođenje metafora predstavlja osobiti problem prevoditeljima, koji često moraju odlučiti doprinosi li upotreba metafore u prijevodu razumijevanju teksta ili ne, a ako je metafora neophodna, na koji je način prevesti da se uklopi u kulturu, odnosno jezik na koji se prevodi. Kada se radi o prijevodu starijeg teksta, poput Chaucerova iz 14. st., napisanog na srednjoengleskom jeziku, zadatak postaje još zahtjevniji jer se tijekom vremena mijenjaju i jezik i kultura, a moguće su i promjene u mentalnom doživljaju svijeta koji nas okružuje. Ipak, dijakronijske studije o razlikama (i/ili sličnostima) u metaforičkom promišljanju još uvijek su rjeđe od sinkronijskih, bilo da je riječ o govornicima jednog te istog jezika, ili o prevođenju s jednog jezika na drugi. Što se tiče srednjovjekovnoga engleskog jezika, jedna od rijetkih studija objavljenih u Hrvatskoj analiza je konceptualizacije ljubavi u srednjovjekovnim engleskim tekstovima, koja uključuje i Canterburyjske priče (u Dijakronijska varijacija u metaforičkim modelima: Razrada metodologije, Mateusza-Milana Stanojevića). Kad je riječ o sinkronijskim istraživanjima, mali se broj znanstvenih radova bavio sustavnom analizom i usporedbom metafora u engleskom i hrvatskom jeziku. Takvu je analizu pjesničkih metafora u okviru kognitivne lingvistike i na temelju vrlo ograničenog broja primjera ponudila je Žic-Fuchs (1992.). Stoga ovaj članak pokušava dati doprinos s jedne strane dijakronijskim istraživanjima metafore, a s druge strane unakrsnoj analizi metafora dvaju jezika različite strukture i povijesnog razvoja, poput engleskog i hrvatskog, i to na korpusu od četrdesetak metafora.

Bitno je istaknuti da su autori i originalnog teksta i njegova prijevoda veliki pjesnici, s posebnim senzibilitetom za upotrebu metafore, pa se sasvim opravdano mogla očekivati upotreba pjesničkih metafora u oba teksta. Još od vremena Aristotelove Retorike uglavnom su pjesničke, odnosno 
književne metafore i bile predmet rasprave retoričara, teoretičara književnosti i filozofa. Do 1980. općenito je prevladavalo mišljenje da pjesničke metafore predstavljaju specifičan tip metafore, za čije je stvaranje potreban poseban talent, a za njihovo razumijevanje određeni napor, što se naslanja na gledišta Gricea (1975.) i Searlea (1980.), koji polazeći od teorije govornog čina (SAT), govore o zahtjevnoj kognitivnoj aktivnosti slušatelja i čitatelja koji najprije treba prepoznati metaforu u tuđem iskazu, potom pretpostaviti nekoliko mogućih značenja te metafore i na kraju odlučiti o kojem je mogućem prenesenom značenju riječ. Lakoff i Johnson u Metaphors We Live By bavili su se prvenstveno konvencionalnim metaforama u svakidašnjem jeziku, pokazavši da one odražavaju način na koji razmišljamo, komuniciramo, djelujemo, odnosno živimo, ali dotakli su se i tzv. inovativnih i maštovitih metafora, koje mogu kreirati novu stvarnost, odnosno strukturirati naš konceptualni sustav na osnovi našeg vlastitog iskustva u kontekstu kulture i društvene okoline u kojima živimo. U kasnijim radovima, međutim, težeći uspostaviti opća načela metaforizacije, Lakoff je nastojao pronaći i objasniti poveznicu između konvencionalnih i pjesničkih metafora na temelju postavki svoje kognitivno-konceptualne teorije. U More Than Cool Reason (1989.) zajedno s Markom Turnerom analizirao je fragmente više književnih tekstova te pokazao da su pjesničke metafore zapravo konvencionalne metafore, koje su razumljive širokoj publici upravo zato jer počivaju na temeljnim konceptima. I Turner na početku predgovora svoje knjige The Literary Mind (1996.) ističe da književni um nije posebna vrsta uma, već je to „naš um”. Po Lakoffu i Turneru inovativne i pjesničke metafore proširenja su, nadogradnje i kombinacije konceptualnih metafora. Drugim riječima, kompleksne pjesničke metafore izgrađene su na temelju jednostavnih. Metaforička kreativnost u poeziji rezultat je upotrebe istih konceptualnih metafora koje pjesnici dijele s drugim ljudima i upravo je to razlog, kako sugeriraju Lakoff i Turner, zašto čitatelji pri interpretaciji pjesničkog teksta pribjegavaju već postojećim konceptualnim preslikavanjima radije nego stvaranju novih (xi-xii). U prilog takvom viđenju pjesničke metafore idu mnoga suvremena istraživanja u području kognitivne psihologije, antropologije i psiholingvistike koja su potvrdila da je način na koji razmišljamo metaforične prirode. Nedavna psiholingvistička istraživanja pokazala su da ispitanici čitajući poeziju prizivaju u svijest već ranije usvojene konceptualne metafore u korelaciji s pojedinim jezičnim izrazima, odnosno da ključni aspekti pjesničke misli i jezika proizlaze iz konceptualnih metafora (vidi npr. Citron et al.). Ovaj će članak, između ostalog, pokazati jesu li metafore u pjesničkom Chaucerovu djelu i u pjesničkom Paljetkovu prijevodu jednostavne 
konceptualne metafore iz svakidašnjeg života, ili potpuno nove, prvi put upotrjebljene pjesničke metafore.

Međutim, glavni cilj s kojim smo krenuli u istraživanje bio je identificirati konceptualne metafore u srednjoengleskom tekstu Mlinareva proslova i Mlinareve priče te pronaći ekvivalente u hrvatskom prijevodu Luke Paljetka (Canterburyjske priče, Znanje 1986., Zagreb), kako bi se došlo do zaključka funkcioniraju li isti metaforički koncepti u oba jezika, odnosno u obje kulture, te ako funkcioniraju, preklapaju li se izvorni pojmovi u njihovim metaforičkim jezičnim izrazima velikim dijelom, ili tek u manjoj mjeri, s obzirom na vremenski period od otprilike 600 godina koliko je prošlo između originalnog teksta i prijevoda, te s obzirom na razlike u kulturama. Identifikacija konvencionalnih metafora pokazat će koji je tip metafora najčešći, a koji najrjeđi u upotrebi kod engleskih i hrvatskih govornika kad su u pitanju određeni metaforički ciljevi. Tematika i ciljevi istraživanja zahtijevali su logično primjenu komparativno-kontrastivne metode u okviru dijakronijske lingvistike.

Članak se sastoji od pet poglavlja. Drugo poglavlje donosi pregled Chaucerovih metafora svrstanih prema njihovoj kognitivnoj funkciji kako je definiraju Lakoff i Johnson u okviru svoje kognitivnokonceptualne teorije, tj. na strukturne (potpoglavlje 2.1.), ontološke (2.2.) i orijentacijske (2.3.). Chaucerovi citati označeni su glavnim brojevima te popraćeni kratkim objašnjenjima na koga ili što se odnose, kako bi bili razumljivi današnjim čitateljima, s obzirom na to da ih navodimo izvan konteksta i na staroengleskom jeziku. Potom slijedi analiza metafora identificiranih u citatima, tj. njihova metaforičkog koncepta i jezičnog izraza. U 3. poglavlju uspoređuju se Chaucerove metafore s Paljetkovima u tabličnoj formi. Tako se u potpoglavlju 3.1. najprije navode primjeri metafora s identičnim konceptima i potpuno ekvivalentnim izrazima u originalnom tekstu i prijevodu, u 3.2. primjeri identičnih koncepata, ali različitih izraza u izvornom i ciljanom tekstu, u 3.3. primjeri različitih metaforičkih koncepata i različitih izraza u oba teksta te u 3.4. primjeri engleskih metafora prevedenih hrvatskim izrazima doslovnog značenja. Četvrto poglavlje donosi analizu podataka iskazanih u tablicama. Osim konvencionalnih metafora, u fokusu su i one u kojima postoje očite razlike u metaforičkom konceptu i/ili izrazu te se pokušavaju objasniti razlozi njihove upotrebe. Potom slijedi zaključak. 


\section{Chaucerove metafore i njihova klasifikacija prema konceptualno-kognitivnoj teoriji}

\subsection{Strukturne metafore}

Ciljevi (target domain) strukturnih metafora u Mlinarevu proslovu i Mlinarevoj priči ponajviše su emocije glavnih likova, među kojima je dominantna ljubav, a potom osobine likova, njihove aktivnosti i događaji koji im se dešavaju, njihovi međusobni odnosi te vrijeme i smrt. Kako su metafore emocija najčešće, počinjemo s njima.

Mlada Alisoun bila je tako zamamna da Chaucer njezinoj ljepoti i vrckavom ponašanju posvećuje redom četrdeset stihova, a usred tog opisa nalazimo sljedeći stih:

And sikerly she hadde a likerous ye. (3244)

Srednjoengleski pridjev likerous/lickerish „ugodan nepcu”, nastao je od imenice licker /liquor „tekućina”, (kasnije „alkohol”) te od njega potječe današnja riječ lecherous „pohotan, razvratan”. Sama etimologija riječi ukazuje na činjenicu da metaforički izraz pohotno oko počiva na strukturnom konceptu POHOTA JE ŽEĐ.

I Nicholasu i Absolomu zapela je lijepa Alisoun za oko te su joj se oba udvarala. Međutim, dok ju je Nicholas zaveo u tren oka, Absolonu to, uz sav trud, nikako nije polazilo za rukom, i to stoga, mislio je, jer „uvijek onaj bliži i vještiji čini onog daljeg - mrskim”.

(2) Men seyn right thus, 'Alwey the nye slye Maketh the ferre leeve to be looth.' By cause that he fer was from hire sight, This nye Nicholas stood in his light. (3392-5)

Ova četiri stiha u cjelini pokazuju da LJUBAV ZAHTJEVA FIZIČKU BLIZINU, međutim, u zadnjem stihu nalazimo još jednu strukturnu metaforu. Izraz This nye Nicholas stood in his light znači „Nicholas je zauzeo njegovo mjesto”, ali može se protumačiti i kao „Nicholas je priječio njegovu sreću”, s obzirom na to da je jedno od značenja imenice light u srednjoengleskom „radost, sreća” ( MED). U tome iščitavamo i metaforički koncept SREĆA JE SVJETLOST, (kao npr. u modernim 
engleskim izrazima: You are the sunshine of my life, There was a light in her eyes, When he saw her, he lit up, itd.), odnosno NESREĆA JE NEDOSTATAK SVJETLA.

Pun nade da će je konačno uspjeti osvojiti, Absolon se jednog dana pred zoru uputio do Alisounine kuće te joj je pod prozorom nježno šaptao:

(3) That for youre love I sweete ther I go. (3702)

Izraz jasno pokazuje da je LJUBAVNA STRAST percipirana kao VATRA, što nije ništa drugo već odraz tjelesne reakcije na emocije. Blage emocije izazivaju lagano širenje topline po tijelu, a snažne - vatru ili čak groznicu, uslijed brzog kolanja krvi i povišenja tjelesne temperature. Tom se prigodom Alisoun okrutno poigrala s Absolonom, ostavivši ga poniženog i ismijanog, pa se njegova „vruća ljubav” naglo „ohladila” i „ugasila”.

(4) His hoote love was coold and al yqueynt! (3754)

Kao što je Absolon snažnu ljubav i strast iskusio kao vatru, tako je NEDOSTATAK LJUBAVI doživio kao NEDOSTATAK TOPLINE. Iz tjelesnog iskustva poznato je da se kod stišavanja emocija, smanjuje brzina rada srca te se tijelo hladi. Kad emocije naglo iščeznu, osjećamo STUDEN.

Absolonova ljubav nestala je netragom, a zamijenili su je bijes i mržnja.

(5) For he was heeled of his maladie. (3757)

Izraz bio je izliječen od svoje bolesti jasno pokazuje da se LJUBAV shvaća kao BOLEST.

Prije ovog nemilog događaja Absolon se silno trudio ugoditi Alisoun te je bio, bez obzira na to što mu je Nicholas stajao na putu, pun nade i činilo mu se „da sve ide više nego dobro”.

(6) This passeth forth; what wol ye bet than weel? (3370)

Upotreba metaforičnog izraza this passeth forth „tako to ide dalje”, s glagolom passen „koračati”, otkriva da se TIJEK VREMENA poima KAO KRETANJE, a VRIJEME KAO FIZIČKI PROSTOR po kojem hodamo. Stoga nije čudno što riječ space od sredine 14. st. označava i „vremensko razdoblje” i „zemlju, teritorij; razdaljinu između dvije točke” (MED), pa izraz I have no space u sljedećim Chaucerovim stihovima shvaćamo kao „nemam vremena”: 
(7) Go now thy wey, I have no lenger space To make of this no lenger sermonyng. (3596-7) Što je Absolon više udvarao Alisoun, to ga je ona više prezirala i sprdala se s njim, „praveći ga majmunom".

(8) And thus she maketh Absolon hire ape. (3389)

Izraz je nastao prema konceptu LJUDI SU ŽIVOTINJE, koji se često koristi i u književnosti i u svakidašnjem govoru, jer mnoge ljudske osobine podsjećaju na životinjske. Kako se ovdje radi o Absolonovoj gluposti i nespretnosti, metaforički koncept navedenog izraza jest NEPRIHVATLJIVO PONAŠANJE ŽIVOTINJSKO JE PONAŠANJE. Međutim, uspoređivanje ljudi s životinjama nema uvijek negativne konotacije u tekstu. Sljedeći primjer, u kojem zaljubljeni Absolon naziva Alisoun my faire bryd „svojom lijepom ptičicom”, pokazuje i suprotno, tj. da POŽELJNO PONAŠANJE također može biti ŽIVOTINJSKO PONAŠANJE:

(9) What do ye, hony-comb, sweete Alisoun, My faire bryd, my sweete cynamome? (3698-9) U istim stihovima nalazimo i drugi strukturni koncept - LJUDI SU BILJKE, jer je Alison Absolonov cimet, dragocjena orijentalna biljka, čiji se prah dodaje u hranu zbog svog ugodnog okusa, pa je Alisoun sweete cynamome „slatki cimet”. Ona je i hony-comb, pčelinja „medena saća”, dakle, slatka kao med, pa je vidljivo da OSJEĆAJE strukturiramo KAO HRANU, a UGODNE OSJEĆAJE, poput ljubavi, KAO SLATKU HRANU, i to na temelju tjelesnog iskustva.

Spomenuti koncept LJUDI SU ŽIVOTINJE otkrivamo i u Mlinarevu proslovu, u Mlinarevim riječima:

(10) Who hath no wyf, he is no cokewold. (3152)

Mlinar, naime, ne misli da je njegova priča o tesaru rogonji sramotna jer, kako stoji u prijevodu, „Tko nema žene, taj rogonja nije”. Ovdje se metaforičnost otkriva tek uvidom u etimologiju riječi cokewold „rogonja”, koja dolazi od starofrancuske cucuault, čija osnova cocu sadržava u sebi dva značenja: „glasanje ptice kukavice” te „luda, bena” (Klein 381). Semantička poveznica ovih riječi je u tome što ptica kukavica nikad ne ostaje s mužjakom duže vrijeme, pa svog partnera čini rogonjom.

Kako bi bezbrižno proveo noć s Alisoun, Nicholas je uvjerio tesara da dolazi opći potop, sličan 
biblijskom, te da se od sigurne smrti može spasiti samo ako se sakrije u korito obješeno visoko pod krovom i tu dočeka zoru. Od same pomisli na to razbuktala se tesareva mašta.

(11) A men may dyen of imaginacioun, So depe may impressioun be take. (3612-3)

Zamišljene slike mogu biti toliko strašne da od njih čovjek može „puknuti”, štoviše, od mašte „može i umrijeti”, pa je vidljivo da BUJNA MAŠTA UZROKUJE SMRT. Ovdje otkrivamo i ontološku metaforu po kojoj je mašta posuda u koju spremamo razne supstance, tj. dojmove. Površni dojmovi, kako kaže sama riječ, ostaju na površini posude, dok se oni najjači „uzimaju” (teken) i spremaju „vrlo duboko” (so depe), na njezino dno.

Stari je tesar bio toliko izmoren pripremama za spas od potopa da je navečer zaspao najtvrđim snom, snom bez buđenja i bez osjeta vanjskog svijeta.

(12) The dede sleep, for wery bisynesse, Fil on this carpenter right, as I gesse. (3643-4) Sintagma mrtvi san najizravniji je izraz koncepta SMRT JE SAN. Tesar je odmah zaspao, tj. kako Chaucer kaže „san je odjednom pao na njega”, pa glagol „pasti” ukazuje na to da PROMJENA STANJA UKLJUČUJE KRETANJE, u ovom slučaju naglo.

Kad su Alisoun i Nicholas namagarčili Absolona, jedina misao bila mu je - osvetiti im se. Sve drugo bilo je nevažno, pa i kovačeva šala na njegov račun.

(13) This Absolon ne roghte nat a bene Of al his pley; no word agayn he yaf; (3772-3) Izraz „(za to) nije davao ni boba” pokazuje da ljudski um percipira sve što je NEVAŽNO kao MALO.

U sljedećem primjeru nailazimo na još jedan izraz prenesenog značenja, koji je zapravo metonimijski. Naime, Lakoff i Johnson smatraju metonimiju podvrstom metafore u kojoj jedna pojmovna cjelina, tzv. sredstvo (vehicle) omogućava pristup drugoj, tj. cilju (target) unutar istog područja, bilo da se radi o CJELINI ZA DIO ili DIJELU ZA CJELINU.

(14) He hadde more tow on his distaf Than Gerveys knew. (3774-5)

Izraz „imao je više kudjelje na preslici nego je Gerveys znao” znači „imao je posla više nego je Gerveys mogao pretpostaviti”, pa se radi o metonimijskom konceptu DIO ZA CJELINU, u kojoj presti stoji umjesto raditi, činiti. Sličan metonimijski izraz, tipa DIO ZA CJELINU, nalazimo i u 
sljedećem primjeru, u kojem je cilj (target) metonimije raditi beskoristan posao, a sredstvo (vehicle) blowe the bukkes horn „puhati u ovnov/volinji rog”:

(15) She loveth so this hende Nicholas That Absolon may blowe the bukkes horn. (3386-7)

Svašta se dogodilo te noći u tesarevoj kući. Alisoun je prevarila ljubomornog muža i poigrala se s jadnim Absolonom, Absolon se osvetio Nicholasu, a od silne vike i buke probudio se tesar, koji je pao s krova i pri padu slomio ruku. Potom su u kuću nagrnuli susjedi.

(16) The neighebores, bothe smale and grete. (3826)

Izraz smale and grete „mali i veliki” možemo shvatiti u smislu u kojem ga donosi Paljetak, tj. star i mlad, ali ga možemo tumačiti i metaforički, u značenju u kojem se počeo koristiti u Chaucerovo doba, kao „nevažni i važni”, odnosno „pučani i gospoda”, pa opet dolazimo do gore spomenutog koncepta NEVAŽNO JE MALO, VAŽNO JE VELIKO.

\subsection{Ontološke metafore}

Ontološke metafore one su kojima apstraktne pojmove koncipiramo uz pomoć materijalnih ili konkretnih. Po teoriji Lakoffa i Johnsona jedna od glavnih ontoloških metafora jest tzv. metafora spremnika (the container metaphor), koja zapravo obuhvaća dva koncepta, jedan po kojem su osobe spremnici/posude za ideje, emocije, stanja, aktivnosti itd., te drugi, po kojem su emocije, misli ili stanja omeđeni prostori ili prostorije u kojima osobe borave. Prvi od spomenutih koncepata najčešće nalazimo u Mlinarevu proslovu i Mlinarevoj priči u opisu emocionalnih i duševnih stanja Chaucerovih likova. Dok stanje traje, lik se nalazi unutar tog prostora, a kad stanje iščezne, osoba se nalazi izvan njega, odnosno izlazi iz njega. Tako tesar, gledajući naizgled poludjelog Nicholasa, zaključuje da je ovaj in despeir „u očaju”, a sluškinja da je in maladye „u bolesti”:

(17) This carpenter wende he were in despeir. (3474)

(18) She trowed that he was in maladye. (3416)

Jedini način da Nicholas ozdravi jest da prekine s pretjeranim učenjem, tj. da izađe out of his studiyng, doslovno „izvan učenja”:

(19) He shal out of his studiyng, as I gesse. (3467) 
Sam Chaucer na kraju Mlinareva proslova doslovno savjetuje čitateljima da ga izvuku „iz krivnje” jer donosi prostačku priču. Naime, on za nju nije odgovoran, već Mlinar, a i drugi koji pričaju slične priče, pa kaže:

(20) Avyseth yow, and put me out of blame. (3185)

Međutim, nije uvijek osoba ta koja je smještena u neko emocionalno stanje ili u neki omeđeni prostor. Ponekad se sama osoba poima kao posuda ili spremnik, u koju su smještene različite supstance, odnosno osjećaji. Tako Alisoun kaže za starog Johna:

(21) Myn housbonde is so ful of jalousie. (3294)

Osim metafore spremnika i omeđenog prostora, Chaucer koristi i druge tipove ontoloških metafora, koji nam omogućavaju da shvatimo apstraktne pojmove kao materijalne predmete određenog oblika i mjerljivih dimenzija kojima možemo manipulirati. Već na samom početku Proslova Krčmar zadovoljno kaže:

(22) This gooth aright; unbokeled is the male. (3115)

Izraz unbokeled male „razvezana vreća” odnosi se na proces pričanja, koje je izvrsno započelo. Ovdje uz ontološku nalazimo i strukturnu metaforu jer se mentalna aktivnost koja uključuje ograničenu fizičku aktivnost (govornih organa) opisuje uz pomoć čisto fizičke radnje (razvezivanja vreće), a ova pak podrazumijeva upotrebu sile. Dakle, STATIČKA AKTIVNOST strukturira se kao DINAMIČKA RADNJA S UPOTREBOM FIZIČKE SILE.

(23) So he may fynden Goddes foysoun there, Of the remenant nedeth nat enquere. (3165-6) Mlinar ovdje tumači hodočasnicima da muž ne smije zabadati nos u tajne svoje žene, pa i kad ga vara s drugima, sve dok sam nije uskraćen u svojim potrebama. Ljubav koju žena posjeduje jest Goddes foysoun „božje blago”, a ono se kao svaka količina materijalnog blaga može izmjeriti i dijeliti, jedan dio mužu, a remenant „ostatak” drugima. O starom tesaru, u čijoj se duši pred nadolazeći potop miješa strah od smrti s boli, tugom i strepnjom, Chaucer kaže:

(24) Lo, which a greet thyng is affeccioun! (3611)

Affeccioun „osjećaj; emocionalni nemir ili uzbuđenje” za Chaucera je predmet, i to ne bilo kakav, već veliki (greet). I drugi apstraktni pojmovi, kao što su pogledi i Vitezova priča opisani su kao 
materijalni predmeti, koji se mogu baciti (poput kamena npr.), odnosno povući u nekom smjeru. Tako u Mlinarevoj priči Absolon baca poglede na lijepe žene, a u Mlinarevu proslovu hodočasnici zaključuju da se dirljiva i poučna Vitezova priča treba povući u sjećanje:

(25) And many a lovely look on hem he caste. (3342)

(26) And worthy for to drawen to memories. (3112)

Kako baciti znači „zamahom i puštanjem iz ruke promijeniti mjesto čemu ili komu”, a povlačiti (koga, što) „vući po tlu” (HJP), opravdano je reći da se GLEDANJE i PAMĆENJE poima kao KRETANJE U ODREĐENOM SMJERU, pa se u posljednja dva slučaju isprepliću ontološke i strukturne metafore.

\subsection{Orijentacijske metafore}

Temeljna orijentacijska metafora po Lakoffu i Johnsonu jest DOBRO JE GORE, a temelji se na uspravnu držanju ljudskog tijela u fizičkom prostoru te ukazuje na ljudsku orijentiranost k svemu što je gore, kao prema dobru općenito. Iz ovog koncepta slijede i drugi, npr.

SRETNO/ZDRAVO/VRLO JE GORE. Naravno, vrijedi i obratno - LOŠE JE DOLJE, s odgovarajućim potkonceptima.

(27) This man is falle, with his astromye, In soome woodnesse or in som agonye. (3451-2)

Lukavi Nicholas potrudio se uvjeriti tesara da je u zvijezdama otkrio kako se sprema potop, a tesar, vidjevši ga prije toga kako noćima bulji u nebo, zaključuje da je jadni mladić „zapao u ludilo ili nekakvu agoniju”. Glagolom fallen „pasti, zapasti” Chaucer opisuje promjenu Nicholasova duševnog stanja, pa se njime izražava strukturna metafora PROMJENA JE KRETANJE. Međutim, u ovom slučaju radi se konkretno o promjeni iz zdravog mentalnog stanja u loše, pa je izraz stvoren i na orijentacijskom konceptu ZDRAVO JE GORE, BOLESNO JE DOLJE. Glagol fall „pasti” metaforičan je sam po sebi, jer su njegova staroengleska značenja „propasti, raspadati se, umrijeti” zapravo nastala prema fizičkom doživljaju pada u prostoru, pa jasno pokazuju da je kretanje prema tlu izrazito negativna promjena.

(28) Or if men asked hym what sholde bifalle. (3197) 
Tesar je studenta smatrao silno učenim i činilo mu se da je želio imati odgovore na sve, pa i na upite ljudi što se sprema u budućnosti.

Glagol befall „dogoditi se” izvedenica je glagola kretanja fall „pasti” i prefiksa be „oko(lo)”, te kao i fall može metaforički izražavati promjenu. Ovdje, međutim, befall izražava orijentacijski koncept NEPOZNATO JE GORE, POZNATO JE DOLJE, jer ono što je palo (na tlo) ispred ili oko nas, to nam je blizu, pa nam je onda i poznato, a ono što je visoko u zraku i teško vidljivo nepoznato nam je. Zato se npr. kaže My birthday will fall on Friday this year, ali i That's still in the air.

(29) Thou art a fool; thy wit is overcome. (3135)

Kad Krčmar shvati da ne može spriječiti potpuno pijanog Mlinara da nakon Viteza ispriča svoju priču, odustaje od nagovaranja i kaže mu doslovno: „Luda si; um ti je svladan.” Sama struktura glagola overcome „nadvladati, nadjačati, pobijediti; obuzeti” ukazuje na to da KONTROLU, (PRE)VLAST, UPRAVLJANJE doživljavamo kao nešto što JE GORE, odnosno IZNAD (over) nekoga ili nečega. Isti koncept nalazi se i u pozadini sljedeća dva izraza:

(30) How that a clerk hath set the wrightes cappe. (3143)

Izraz set the cap, doslovno „staviti/namjestiti nekome kapu” znači „dosegnuti vrh (glavu ljudskog tijela), tj. uspješno završiti nešto” i to lukavstvom, odnosno „nadmudriti” koga.

(31) For whan he spak, he was anon bore doun. (381)

Na kraju Mlinareve priče Alisoun i Nicholas spretno su uvjerili susjede da je stari tesar poludio umišljajući potop te su svaku njegovu riječ odmah zanijekali. Tesar je bio bore doun, doslovno „pritisnut dolje”, odnosno nadjačan, poražen.

\section{Usporedba engleskih metafora iz Mlinareva proslova i Mlinareve priče i njihovih hrvatskih ekvivalenata}

U prethodnom poglavlju naveden je 31 citat iz Mlinareva proslova i Mlinareve priče, u kojima je pronađeno i objašnjeno 37 Chaucerovih metafora. Od toga 20 je strukturnih, 9 ontoloških, a 4 su orijentacijske. Preostale metafore po svojim su kognitivnim funkcijama mješovite jer izražavaju različite aspekte jednog te istog ciljnog pojma. Tako su 3 metafore, (22), (25) i (26) ontološko- 
strukturne, dok je 1 orijentacijsko-strukturna (27). Uz to, pronađene su i dvije metonimije, koje kao takve nisu uvrštene u tablice.

Usporedbu srednjoengleskih i modernih hrvatskih metafora započinjemo metaforama identičnima u oba jezika.

\subsection{Identični metaforički koncepti i potpuno ekvivalentni metaforički izrazi u oba teksta/jezikaTablica 1. Identični metaforički koncepti i potpuno ekvivalentni metaforički izrazi u oba teksta/jezika}

\begin{tabular}{|c|c|c|c|}
\hline Primjer & Metaforički koncept & Chaucerov metaforički izraz & Paljetkov metaforički izraz \\
\hline & strukturni & & \\
\hline (1) & POHOTA JE ŽEĐ & a likerous eye & požudnog oka \\
\hline $\begin{array}{l}\text { (3) } \\
\text { (4) }\end{array}$ & LJUBAVNA STRAST JE VATRA & $\begin{array}{l}\text { his hoote love } \\
\text { for youre love I sweete; }\end{array}$ & $\begin{array}{l}\text { vrela mu strast } \\
\text { od ljubavi se znojim; }\end{array}$ \\
\hline (4) & NEDOSTATAK LJUBAVI JE STUDEN & $\begin{array}{l}\text { his hoote love was cold and al } \\
\text { yqueyn; }\end{array}$ & vrela mu strast ohladila se sva; \\
\hline (5) & LJUBAV JE BOLEST & he was heeled of his maladie; & izliječen bje od te svoje boli; \\
\hline$(8)$ & $\begin{array}{l}\text { NEERIHVATLJIVO PONAŠANJE JE } \\
\text { ŽIVOTINJSKO PONAŠANJE }\end{array}$ & she maketh Absolon hire ape; & majmunom ona pravila je njega; \\
\hline (9) & $\begin{array}{l}\text { POŽELJNO/UMILNO PONAŠANJE JE } \\
\text { ŽIVOTINJSKO PONAŠANJE }\end{array}$ & my faire byrd & ptičice moja \\
\hline (9) & LJUDI SU BILJKE & my sweete cynamome & cimete medeni \\
\hline (9) & $\begin{array}{l}\text { UGODNI OSJEĆAJI (LJUBAV) SLATKA } \\
\text { SU HRANA }\end{array}$ & $\begin{array}{l}\text { sweete Alisoun; } \\
\text { hony-comb, ..., } \\
\text { my sweete cynamome; }\end{array}$ & $\begin{array}{l}\text { Alison slatka; } \\
\text { cimete medeni; }\end{array}$ \\
\hline (11) & BUJNA MAŠTA JE SMRT & a man may dyen of imaginacioun; & od umišljaja skončat zna čeljade; \\
\hline (12) & SMRT JE SAN & the deede sleep & mrtvi san \\
\hline (13) & NEVAŽNO JE MALO & ne rohte nat a bene; & ne da ni boba; \\
\hline & ontološki & & \\
\hline (23) & LJUBAV JE DRAGOCJENI PREDMET & Goddes foysoun & božje blago \\
\hline (23) & LJUBAV JE DJELJIVA KOLIĆINA & the remenant & višak \\
\hline
\end{tabular}

Ekvivalentnost izraza nije potpuna samo u primjerima (4) i (9), u kojima je Paljetak ispustio fraze and al yqueynt „i potpuno ugašena [ljubav]” te hony-comb „medena saćo”, međutim, ostatak izraza identičan je originalu te se prepoznaje isti metaforički koncept. 


\subsection{Identični metaforički koncepti u oba teksta/jezika - različiti} metaforički izraziTablica 2. Identični metaforički koncepti u oba teksta/jezika - različiti metaforički izrazi

\begin{tabular}{|c|c|c|c|}
\hline Primjer & Metaforički koncept & Chaucerov metaforički izraz & Paljetkov metaforički izraz \\
\hline & strukturni & & \\
\hline (2) & LJUBAV ZAHTIJEVA FIZIČKU BLIZINU & $\begin{array}{l}\text { Men seyn right thus, 'Alwey the nye } \\
\text { slye Maketh the ferre leeve to be } \\
\text { looth', By cause that he fer was from } \\
\text { hire sight, This nye Nicholas stood in } \\
\text { his light; }\end{array}$ & $\begin{array}{l}\text { Puk dobro kaže: 'Tko bliže oltara } \\
\text { Stoji, taj mnogo bolje misu čuje'. } \\
\text { Absolon..., jer na oku joj ne bje, nije } \\
\text { bio Onako kao Nikola joj mio; }\end{array}$ \\
\hline (10) & LJUDI SU ŽIVOTINJE & who hath no wyf, he is no cokewold; & tko nema žene, taj rogonja nije; \\
\hline$(16)$ & NEVAŽNO JE MALO* & $\begin{array}{l}\text { the neighbores, bothe smale and } \\
\text { grete }\end{array}$ & susjedi skupa svi, i star i mlad \\
\hline (19) & PROMJENA AKTIVNOSTI JE KRETANJE & he shal out of his studyng; & od učenja proć će ga volja; \\
\hline \multirow[t]{2}{*}{$(22)$} & $\begin{array}{l}\text { STATIČKA AKTIVNOST JE DINAMIČKA } \\
\text { RADNJA S UPOTREBOM SILE }\end{array}$ & unbokeled is the male; & puče konop vreći; \\
\hline & ontološki & & \\
\hline$(11)$ & DOJAM JE MATERIJALNI PREDMET & so depe may impressioun be take; & duboki dojam; \\
\hline
\end{tabular}

\subsection{Različiti metaforički koncepti - različiti metaforički izrazi Tablica 3. Različiti metaforički koncepti - različiti metaforički izrazi}

\begin{tabular}{|c|c|c|c|c|}
\hline Primjer & $\begin{array}{l}\text { Metaforički koncept u } \\
\text { engleskom jeziku }\end{array}$ & Chaucerov metaforički izraz & $\begin{array}{l}\text { Metaforički koncept u } \\
\text { hrvatskom jeziku }\end{array}$ & Paljetkov metaforički izraz \\
\hline & strukturni & & strukturni & \\
\hline \multirow[t]{2}{*}{ (12) } & $\begin{array}{l}\text { PROMJENA STANJA JE } \\
\text { FIZIČKO KRETANJE }\end{array}$ & $\begin{array}{l}\text { The deede sleep, ..., Fil on } \\
\text { this carpenter right; }\end{array}$ & $\begin{array}{l}\text { PROMJENA STANJA JE } \\
\text { FIZIČKA SILA }\end{array}$ & mrtvi san ... ophrva njega; \\
\hline & ontološki & & ontološki & \\
\hline \multirow[t]{2}{*}{$(20)$} & $\begin{array}{l}\text { OSJEĆAJ JE BORAVAK U } \\
\text { OMEĐENOM PROSTORU }\end{array}$ & put me out of blame; & $\begin{array}{l}\text { OSJEĆAJ JE PREDMET KOJI } \\
\text { SE POSJEDUJE }\end{array}$ & krivo nemojte me imat; \\
\hline & ontološki & & strukturni & \\
\hline \multirow[t]{2}{*}{$(21)$} & $\begin{array}{l}\text { OSOBA JE POSUDA PUNA } \\
\text { OSJEĆAJA }\end{array}$ & so ful of jalousie & SNAŽNI OSJEĆAJU SU VATRA & sav od ljubomore gori; \\
\hline & ontološki & & strukturni & \\
\hline \multirow[t]{2}{*}{$(24)$} & MAŚTA JE VELIKI PREDMET & $\begin{array}{l}\text { Lo, which a greet thing is } \\
\text { affeccioun! }\end{array}$ & MAŚTA JE SILA & $\begin{array}{l}\text { Gle, kako silna mašta biti } \\
\text { znade! }\end{array}$ \\
\hline & orijentacijski & & ontološki & \\
\hline (29) & $\begin{array}{l}\text { BITI PODLOŽAN KONTROLI } \\
\text { ZNAČI BITI DOLJE }\end{array}$ & thy wit is overcome; & PAMET JE PREDMET & pamet posve ti je tupa; \\
\hline
\end{tabular}




\subsection{Engleske metafore - hrvatski izrazi doslovnog značenja}

\section{Tablica 4. Engleske metafore - hrvatski izrazi doslovnog značenja}

\begin{tabular}{|c|c|c|c|}
\hline Primjer & Metaforički koncept u engleskom & Chaucerov izraz & Paljetkov izraz \\
\hline & strukturni & & \\
\hline \multirow[t]{2}{*}{ (6) } & VRIJEME JE KRETANJE & this passeth forth & tako bje \\
\hline & ontološki & & \\
\hline $\begin{array}{l}\text { (17) } \\
(18)\end{array}$ & $\begin{array}{l}\text { FIZIČKO STANJE JE BORAVAK U } \\
\text { OMEĐENOM PROSTORU }\end{array}$ & $\begin{array}{l}\text { he were in despair; } \\
\text { he was in maladye; }\end{array}$ & $\begin{array}{l}\text { s njim dobro nije; } \\
\text { bolestan je; }\end{array}$ \\
\hline$(25)$ & POGLED JE PREDMET & many a lovely look on hem he caste; & zaljubljeno ih gledajuć u zjene \\
\hline \multirow[t]{2}{*}{$(26)$} & SJEĆANJE JE PREDMET & for to drawen to memories & da zapamti je sva'ko \\
\hline & orijentacijski & & \\
\hline (27) & BOLESNO JE DOLJE & $\begin{array}{l}\text { this man is falle, with his astronomye, } \\
\text { in soome woodnesse; }\end{array}$ & od zvjezdoznanstva boluje stvor taj; \\
\hline$(28)$ & POZNATO JE DOLJE & what sholde bifalle & kakve će se stvari zbiti \\
\hline (30) & IMATI NADMOĆ ZNAČI BITI GORE & $\begin{array}{l}\text { how a clerc hath set the wrightes } \\
\text { cappe }\end{array}$ & kako se školar domogao cilja \\
\hline (31) & $\begin{array}{l}\text { BITI PODLOŽAN KONTROLI ZNAČI } \\
\text { BITI DOLJE }\end{array}$ & he was bore doun; & zanijekaše \\
\hline
\end{tabular}

\section{Analiza podataka prikazanih u tablicama}

Tablica br. 1 pokazuje da je gotovo pola Chaucerovih metafora (15 od 37) aktivno i u današnjem hrvatskom jeziku, tj. da hrvatski govornici upotrebljavaju potpuno ekvivalentne jezične izraze i iste metaforičke koncepte kao i srednjoengleski. Za ove metafore možemo reći da su konvencionalne. Vidljivo je da su sve osim dvije strukturnog tipa te da su im najčešći metaforički ciljevi - ljubav i ljubavna strast.

Podaci iz tablice br. 2 ukazuju na to da identične metaforičke koncepte u oba jezika, ali izražene na drugačiji način, nalazimo u 6 primjera. I ovdje se većinom radi o strukturnim metaforama (5 od 6). U primjeru br. (2), vidljivo je premetanje Chaucerovih metaforičnih i ne metaforičnih stihova u prijevodu. Tako ne metaforički izraz Men seyn right thus, 'Alwey the nye slye Maketh the ferre leeve to be looth doslovno: „Ljudi pravo kažu: Uvijek bliži i vještiji čini onog daljeg i dragog mrskim", Paljetak prevodi metaforom: Puk dobro kaže: Tko bliže oltara Stoji, taj mnogo bolje misu čuje. S druge strane, Chaucerovu metaforu koja slijedi, tj. This nye Nicholas stood in his light, 
prevodi izrazom doslovnog značenja: nije bio onako kao Nikola joj mio. Uzevši sva četiri stiha kao cjelinu, jasno je da govornici oba jezika LJUBAV shvaćaju KAO FIZIČKU BLIZINU, dok se metafora LJUBAV JE SVJETLOST izgubila u prijevodu. Međutim, ona je svojstvena i hrvatskim govornicima, što se vidi npr. iz izraza ti si sunce moje.

U primjeru (10) moguće je uočiti metaforički koncept LJUDI SU ŽIVOTINJE samo uz poznavanje etimologije uporabljenih izraza. Dok je u osnovi riječi cokewold glasanje vrlo promiskuitetne ptice kukavice, u osnovi hrvatske riječi je rog, koji diči npr. vola. Prema HJP-u vol je životinja, ali i „glup i nedokaziv čovjek trome pameti”. Semantičkom promjenom značenje riječi tijekom vremena u oba se jezika proširilo na „benu” i „rogonju”.

U primjeru (11) u oba jezika nalazimo isti ontološki koncept, međutim dok Chaucer koristi glagolsku metaforu, ističući da se dojmom može manipulirati, uzeti ga u ruke i pohraniti na dno (posude) mašte, Paljetak upotrebljava imeničku metaforu. Suprotno tome, u primjeru (22) Chaucer izražava proces pričanje priča imeničkom metaforom, a Paljetak glagolskom.

Koncept NEVAŽNO JE MALO / VAŽNO JE VELIKO u primjeru (16) vrijedi samo ako smale and grete shvatimo u značenju „prostog i visokog roda”, što je sasvim u skladu sa srednjoengleskom upotrebom.

U primjeru (19) u oba jezika radi se o konceptu PROMJENA ili PREKID AKTIVNOSTI JE KRETANJE, ali on je u engleskom izrazu doživljen kao IZLAZAK OSOBE IZ OMEĐENOG PROSTORA, a u hrvatskom kao KRETANJE UNUTAR OSOBE, odnosno SPREMNIKA. Spomenimo ovdje i metonimije tipa DIO ZA CJELINU koje nalazimo u primjerima (14) i (15). U prvoj Chaucer koristi izraz he hadde more tow on his distaf (than Gerveys knew), doslovno „imao je više kudjelje na preslici nego je Gerveys znao", a Paljetak više toga ima on na glavi. Oba izraza znače imao je on još posla ili obveza. Drugi metonimijski izraz, Absolon may blowe the bukkes horn, „Absolon je mogao puhati u ovnov/volinji rog” znači u danom kontekstu isto što i Paljetkovo mučit se mnogo sve iz petnih žila, naime, „činiti uzaludan posao”. U hrvatskom izrazu vidljivo je da se radi ne samo o beskorisnom, nego i napornom poslu.

Tablica br. 3 prikazuje 5 primjera u kojima nalazimo različite metaforičke koncepte i različite metaforičke izraze u izvornom i ciljanom tekstu. Međutim, u dva slučaja, iako se radi o različitim 
metaforičkim konceptima, podudaraju se tipovi metafora. Tako je (12) primjer strukturne metafore u oba jezika, a (20) primjer ontološke. U primjerima (21), (24) i (29) radi se i o drugačijim konceptima i o drugačijim tipovima metafore.

U primjeru (12) Chaucer kaže da je mrtvi san odmah pao na umornog i potresenog tesara, a Paljetak da ga je mrtvi san ophrvao, pa u engleskom otkrivamo strukturni koncept po kojem se PROMJENA STANJA shvaća kao FIZIČKO KRETANJE, a u hrvatskom kao FIZIČKA SILA koja zarobljava osobu. $U$ engleskom izrazu naglasak je na brzini radnje, a u hrvatskom na njezinoj jačini. Ontološku metaforu (20) put me out of blame, po kojoj je OSJEĆAJ krivnje doživljen KAO BORAVAK U OMEĐENOM PROSTORU, Paljetak prevodi s krivo nemojte me imat, iz koje je razvidno da se OSJEĆAJ shvaća KAO PREDMET KOJI SE POSJEDUJE.

Dok Chaucer kaže za tesara [he is] so ful of jalousie (21), opisujući ga kao posudu punu ljubomore, Paljetak koristi izraz sav od ljubomore gori, utemeljen na konceptu SNAŽNI OSJEĆAJI SU VATRA. Ontološka metafora zamijenjena je strukturnom i u primjeru (24) jer je koncept MAŠTA JE (VELIKI) PREDMET (Lo, which a greet thing is affeccioun!) zamijenjen konceptom MAŠTA JE SILA (Gle, kako silna mašta biti znade!). S druge strane, orijentacijska metafora BITI PODLOŽAN MOĆI ZNAČI BITI DOLJE izrečena je u Chaucera s thy wit is overcome (29), a u prijevodu kao pamet posve ti je tupa, u čijoj je osnovi ontološki koncept PAMET JE PREDMET (u ovom slučaju tup).

U 9 primjera istaknutih u tablici br. 4, koja donosi engleske metafore prevedene na hrvatski izrazima doslovnog značenja, nalazimo jednu strukturnu metaforu, četiri ontološke te četiri orijentacijske. Dodajmo ovdje da je u jednom slučaju Paljetak proširio originalno značenje izraza, a u jednom upotrijebio izraz potpuno drugačijeg značenja (te stoga nije uvršten u ovu tablicu). Prvi se odnosi na izraz he were in despair (17), koji Paljetak prevodi kao s njim dobro nije, a drugi na izraz I have no lenger space (7), doslovno „nemam više vremena”, preveden je kao - osim svega toga.

Primjeri iz tablica br. 3 i 4, u kojima nalazimo različite metaforičke koncepte i izraze u dva jezika, odnosno metaforičke koncepte u engleskom bez metaforičkih ekvivalenata u hrvatskom prijevodu, posebno su zanimljivi za temu ovog članka. S obzirom na kognitivnu funkciju metafore, nameću nam pitanje je li razlog spomenutim razlikama drugačija mentalna percepcija ciljnih pojmova u 
engleskih i hrvatskih govornika ili pak nešto drugo. Po našem mišljenju, razlog je jezične prirode, a ne kognitivne. Ako pogledamo svih 5 primjera iz tablice 3, sasvim je sigurno da je Paljetak mogao, baš kao i Chaucer, reći mrtvi san pao je na tesara (12), izbavite me iz krivnje (20), (on je) tako pun ljubomore (21), kako je mašta velika stvar! (24) te tvoj um je svladan/oboren (29). Svi ti izrazi, identični engleskim, bili bi potpuno razumljivi hrvatskim govornicima, jer su utemeljeni na istim metaforičkim konceptima kao u engleskom.

Isto vrijedi i za neke primjere iz tablice br. 4. Paljetak je, poput Chaucera, mogao upotrijebiti izraze tako je to išlo dalje (6), mnogo je zaljubljenih pogleda bacao na njih (25), ovaj čovjek je (za)pao u neko ludilo (27) te što će (koga) zapasti/dopasti (28). Dakle, radi se o konvencionalnim metaforama u oba jezika i u obje kulture. $\mathrm{K}$ tomu, neke od njih imaju identičan semantički razvoj u izvornom i ciljnom jeziku, pa bi bilo logično da su korištene u prijevodu, kao npr. metafore (12) i (27). Osnovno značenje glagola fallen, odnosno pasti, jest „spustiti se na zemlju s visine”, a ono se u oba jezika tijekom vremena proširilo na metaforičko "to happen as a result, to come into being as the consequence or as the product (of something); to change or turn” (MED), odnosno „iznenada se pojaviti, doći [pasti s neba]; pojaviti se kao posljedica čega, dogoditi se; dospjeti, zapasti u kakvo stanje" (HJP). Čak i s dodanim prefiksima ovi glagoli izražavaju slična metaforička značenja: bifallen (be- „by, about” + fallen) „come about, happen, occur”, kao u primjeru (28), i zapasti („za- + pasti”) „pasti (komu) u dio” (HJP), tj. „dogoditi se (komu)”.

Glavni razlog zašto je Paljetak preveo ove metafore onako kako jest leži u činjenici što je morao voditi računa ne samo o sadržaju stihova već i o metrici. Chaucer je, naime, Mlinarev proslov i Mlinarevu priču (kao i većinu Canterburyjskih priča) napisao u desetercima s pet pjesničkih stopa u kojima je naglašen svaki parni slog, ili u tzv. jampskom pentametru. Kako jamb nije tipičan za hrvatski jezik, Paljetak se u prijevodu odlučio za jedanaesterac s prosječno četiri do pet naglašenih slogova te je, kao i Chaucer, redovito rimovao svaka dva stiha. Dakle, imao je vrlo zahtijevan zadatak - prevesti što vjernije sadržaj stihova, uključujući metafore, i održati ritam, što, naravno, nije bilo lako ostvariti. Stoga je u pojedinim slučajevima modificirao originalne metafore, odnosno preveo ih izrazima doslovnog značenja.

U pojedinim slučajevima i gramatika je odigrala svoju ulogu. Tablični podaci pokazuju da su među engleskim ontološkim metaforama relativno česte one tipa spremnika ili posude. U njima tipično 
nalazimo prijedloge in i out of + (apstraktnu) imenicu pri opisu emocionalnih i drugih stanja. Tako nalazimo metaforu be(o)n in despeir „biti u očaju” i be(o)n in maladye „biti u bolesti”, iako je Chaucer umjesto prijedložnih fraza mogao upotrijebiti pridjeve očajan i bolestan. Nadalje, nalazimo i metafore put me out of blame „izvucite me iz krivnje” te he shall out of his studying, doslovno „mora izvan/van iz učenja”, koje su jednako tako mogle biti nemetaforički izrečene kao ne okrivljujte me i on mora prestati učiti. (Naime, i glagol blame i glagol stop bili su u upotrebi u staroengleskom i srednjoengleskom.) Razlog zbog kojeg se Chaucer odlučio za takav izraz čisto je gramatičke prirode. Dok je staroengleski općenito bio sklon glagolskim konstrukcijama, srednjoengleski je pokazivao izrazitu tendenciju k imeničkim, nesumnjivo pod utjecajem francuskog i latinskog, što se vidi u Chaucerovu jeziku. Čak i ako uzmemo u obzir da je Paljetak mogao doslovno prevesti Chaucerovo ben in despeir ili ben in maladye, nije mogao isto učiniti s izrazom he shall out of his studying. Uporaba prijedloga (iz)van uz glagolsku imenicu bila bi potpuno neprirodna, tj. nepravilna u hrvatskom.

I neki drugi izrazi, poput metonimijskih, he hadde more tow on his distaf (than Gerveys knew) (14) $\mathrm{i}$ Absolon may blowe the bukkes horn (15), nisu prevedeni doslovno jer pripadaju srednjovjekovnoj obrtničkoj (tkalačkoj) i poljodjelskoj kulturi koja je davno postala marginalna za većinu hrvatskih (i engleskih) govornika. Uistinu, danas malo tko zna što je preslica, a što kudjelja i nitko više ne puše u volinji rog. Nije stoga čudno što su u modernim engleskim prijevodima Mlinareve priče Chaucerovi izrazi zamijenjeni s He had more business on hand i Absolon may go whistle ( Harvard's GCW 3774, 3387) i sl., dok se u svakidašnjem govoru može čuti u istom značenju to have other (or bigger) fish to fry i to take a hike. Vjerojatno su to bile ondašnje uzrečice, pa je prirodno da ih upotrebljava i Mlinar, kao „narodni” čovjek. Jezik Chaucerovih likova u potpunosti odgovara njihovu staležu. Za razliku od spomenutih, uzrečica ne rohte nat a bene zadržala se u sličnom obliku do danas u oba jezika kao to care not a bean, odnosno ne dati ni (pišljiva) boba (za nešto).

U gornjem smo tekstu pokazali da su metrička ograničenja velikim dijelom utjecala na Paljetkov prijevod originalnih metafora iz Mlinareva proslova i Mlinareve priče. Ipak, indikativno je da je Paljetak najviše promjena učinio prevodeći Chaucerove ontološke i orijentacijske metafore, bilo tako što je osvijetlio njihove ciljeve s nekog drugog aspekta ili još češće tako što je ispustio 
metafore i preveo ih izrazima doslovnog značenja. Kod strukturnih je metafora pak u najvećem broju slučajeva upotrijebio potpuno ekvivalentan izraz, odnosno metaforički koncept identičan onom koji funkcionira u engleskom. Iz toga slijedi da srednjoengleski i današnji hrvatski govornici dijele gotovo istu mentalnu percepciju karakteristika zajedničkih ciljnim i izvornim pojmovima. S druge strane, hrvatski govornici rjeđe od engleskih govornika poimaju apstraktne ciljeve kao predmete te rjeđe doživljavaju ciljne pojmove uz pomoć orijentacije u fizičkom prostoru, ako je moguće suditi iz ograničenog korpusa metafora kakav nalazimo u ovom tekstu. Naime, postotak identičnih metaforičkih koncepata strukturnog tipa u oba teksta, odnosno jezika, iznosi $84 \%$, a ontoloških $16 \%$, kako pokazuju tablice br. 1 i br. 2. Identičnih orijentacijskih metaforičkih koncepata nema. Engleske orijentacijske metafore najčešće su zamijenjene hrvatskim izrazima doslovnog značenja.

Nadalje, prikupljeni podaci pokazuju da nijedan Chaucerov ili Paljetkov metaforički izraz ne možemo smatrati pjesničkim, tj. prvi put primijenjenim u pjesničkom izričaju, jer nam ne otkriva stvarnost na dosad neviđeni ili iskustvom nedoživljeni način. Gotovo sve upotrjebljene metafore bile bi sasvim sigurno razumljive i izvan konteksta u kojem se pojavljuju, odnosno u vrlo različitim kontekstima. Međutim, to nije slučajno. Chaucer je upravo namjerno u liku Mlinara, neukog, prostog čovjeka iz puka, kojemu su k tome i jezik i um otežali od pretjeranog pića, progovorio svakidašnjim govorom s jednostavnim konceptualnim metaforama, kakav i priliči takvoj osobi i stanju, iako uopće ne priliči prigodi hodočašća. To, naravno, samo pojačava humoristički efekt. Međutim, iako je Mlinar, kao uostalom i svi drugi likovi iz Chaucerove šarolike grupe hodočasnika, opisan kao individua, kao sasvim osobit tip, njegov specifični idiolekt sasvim se uklapa u jezik njegova društvenog staleža ili sociolekt, koji se u hijerarhijskoj strukturi feudalnog društva 14. st. jasno razlikuje od jezika više klase - plemstva i visokih crkvenih dostojanstvenika. Chaucer je, kao čovjek velikog iskustva i znanja, bio svjestan jezičnih razlika među engleskim govornicima različitog društvenog položaja i kulture, ali je i prepoznao vrijednost vernakularnih govora, te in je namjerno prenio u Canterburyjske priče, a Paljetak in je, kao izvrstan prevoditelj, vjerno preveo. Unatoč nedostatku pjesničkih metafora u Mlinarevoj priči i Mlinarevu proslovu, oba autora ostvarila su izniman pjesnički izričaj jer se on ne postiže samo upotrebom pjesničkih metafora već $\mathrm{i}$ 
konvencionalnih, te drugim jezičnim sredstvima, kao što su u ovom slučaju rima, metrika, asonanca, aliteracija, usporedbe, epiteti, a pogotovo hiperbola, gradacija, kontrasti, ironija itd.

\section{Zaključak}

U članku smo analizirali korpus od 37 metafora u Chaucerovu Mlinarevu proslovu i Mlinarevoj priči te utvrdili da su njihovi najčešći metaforički ciljevi - osjećaji, i to najprije ljubav i ljubavna strast, a potom nedostatak ljubavi, ljubomora i krivnja. Po brojnosti zatim slijede: osobine likova (glupost, umilnost), stanja likova (bolest/ludilo, očaj) i promjene tih stanja, te odnosi među likovima (superiornost, inferiornost). Ostali metaforički ciljevi obuhvaćaju: smrt, maštu, vrijeme, sjećanje, itd.

Usporedba Chaucerovih metafora s metaforama u Paljetkovu prijevodu pokazuje identičnu uporabu metaforičkih koncepata i izraza u srednjoengleskom i hrvatskom jeziku u nešto manje od polovice ukupnog broja metafora, točnije u 15 od 37, odnosno u $41 \%$ metafora. Za njih se može reći da su konvencionalne, jer funkcioniraju u oba jezika i obje kulture, bez obzira na vremenski razmak od otprilike šest stotina godina. Može se, međutim, sa sigurnošću tvrditi da je broj konvencionalnih metafora u srednjoengleskom i hrvatskom zapravo mnogo veći nego što statistika ovog istraživanja pokazuje, jer je u mnogim primjerima prevoditelj mogao upotrijebiti izraze potpuno ekvivalentne Chaucerovim, a to znači i identične metaforičke koncepte. To se odnosi na dodatnih 9 primjera, odnosno 24 \%. Razlozi zašto je Paljetak modificirao originalne metafore ili ih ispustio, zamjenjujući ih izrazima doslovnog značenja, prvenstveno su jezične, odnosno stilske prirode, s obzirom na to da je originalni tekst - poetski tekst s fiksnom metrikom (tj. točno određenim brojem naglašenih i nenaglašenih slogova te rimom), koju je prevoditelj morao što vjernije prenijeti u vlastiti jezik. Naravno, ovdje treba uzeti u obzir i činjenicu da je prevoditelj ujedno i pjesnik, pa je na izbor metafora, možda i nesvjesno, utjecao njegov vlastiti senzibilitet i afinitet. Gramatički razlozi zanemarivi su usprkos očitim razlikama u strukturi izvornog i ciljnog jezika, koji pripadaju različitim granama indoeuropskih jezika. Iznenađujuće je mali broj metafora koje su modificirane iz kulturoloških razloga, a obuhvaćaju tek dvije metonimije. S obzirom na to da su u engleskim prijevodima na moderni engleski te Chaucerove metonimije redovito zamijenjene suvremenijima, očito više nisu kulturološki prihvatljive ni za engleske govornike. 
O kognitivnim razlikama među govornicima srednjoengleskog i hrvatskog jezika ne može se govoriti jer, kako pokazuju rezultati istraživanja, obje grupe poimaju i iskustveno doživljavaju svijet uz pomoć istovjetnih ili sličnih metaforičnih koncepata. Ipak, važno je istaknuti da je ovo istraživanje pokazalo kako najveći broj konvencionalnih engleskih i hrvatskih metafora obuhvaća strukturne metafore, tj. one koje se temelje na uočavanju sličnosti zajedničkih karakteristika ciljnih i izvornih pojmova obuhvaćenih metaforama. Nasuprot tome, upotreba ontoloških i orijentacijskih metafora manje je učestala u hrvatskom nego u engleskom jeziku, pa je među takvima i manji broj konvencionalnih metafora. Upravo su te metafore najčešće zamijenjene izrazima doslovnog značenja u Paljetkovu prijevodu. Također je očito da ni u originalu ni u prijevodu ne nalazimo nove, originalne, jedinstvene, pjesničke metafore, koje bi ukazivale na razumijevanje svijeta na potpuno nov način, i to zato što je Chaucerov Mlinar, kao tipičan srednjovjekovni predstavnik niže klase, priprost i običan čovjek, pa je takav i njegov jezik. Uostalom, sličnim jezikom govore i ostali pripadnici njegova staleža u Canterburyjskim pričama. lako Mlinar koristi mnoštvo konvencionalnih konceptualnih metafora, one su jednostavne i temeljne i ne nalazimo u tekstu ni njihove nadgradnje ni isprepletenosti ni zgusnutosti. Baš zato što su prisutne u svakidašnjem govoru, razumijemo ih s lakoćom, automatski, bez ikakvog razmišljanja.

Ipak, mora se reći, ako Mlinarev jezik i jest običan, nema sumnje da je sam Mlinar vrlo osebujan i originalan, kao i njegova priča, te da je Chaucer stvorio izvanredno pjesničko djelo, a Paljetak isti takav prijevod. Naime, i jedno i drugo u cjelini je mnogo više od same upotrebe tzv. pjesničke metafore.

\section{Bibliografija}

Chaucer, Geoffrey. Canterburyjske priče. Preveo Luko Paljetak, Znanje, 1986.

Grice, H. Paul. „Logic and Conversion”. Syntax and Semantics, uredili Peter Cole i Jerry L. Morgan, Academic Press, 1975., str. 113-27.

Harvard's Geoffrey Chaucer Website. Harvard University, chaucer.fas.harvard.edu/pages/millersprologue-and-tale. Pristupljeno 24. lipnja 2021.

Hrvatski jezični portal. 2006.-2020., /hjp.znanje.hr. Pristupljeno 3. lipnja 2021. 
Klein, Ernest. A Comprehensive Etymological Dictionary of the English Language. Elsevier Publishing Company, 1966.

Kronfeld, Chana. „Novel and Conventional Metaphors. A Matter of Methodology”. Poetics Today, vol. 2, br. 1b, 1980.-1981., str. 13-24. Jstor, www.jstor.org/stable/1772236.

Lakoff, George. „The Neural Theory of Metaphor”. The Cambridge Handbook of Metaphor and Thought, uredio Raymond W. Gibbs, Cambridge University Press, 2012., str. 17-38. Social Science Research Network, dx.doi.org/10.2139/ssrn.1437794.

Lakoff, George i Mark Johnson. Metaphors We Live By. University of Chicago Press, 1980.

Lakoff, George i Mark Turner. More Than Cool Reason: A Field Guide to Poetic Metaphor. University of Chicago Press, 1989.

Middle English Dictionary. quod.lib.umich.edu/m/middle-english-dictionary/dictionary. Pristupljeno 22. svibnja 2021.

Ortony, Andrew. Metaphor and Thought. Cambridge University Press, 1993.

Rasse, Carina, et al. „Conceptual Metaphors in Poetry Interpretation: A Psycholinguistic Approach". Language and Cognition, vol. 12, 2020., str. 310-42.

Robinson, F. N. The Works of Geoffrey Chaucer. Oxford University Press, 1957.

Searle, John. „The Background of Meaning." Speech Act Theory and Pragmatics, uredili Ferenc Kiefer i Manfred Bierwisch, D. Reidel Publishing Company, 1980., str. 22-43.

Stanojević, Mateusz-Milan. Dijakronijska varijacija u metaforičkim modelima: Razrada metodologije. Sveučilište u Zadru, 2008.

Steen, Gerard. „The Paradox of Metaphor: Why We Need a Three-Dimensional Model of Metaphor". Metaphor and Symbol, vol. 23, br. 4, 2008., str. 213-41.

Turner, Mark: The Literary Mind. Oxford University Press, 1996.

Žic Fuchs, Milena. „Konvencionalne i pjesničke metafore”. Filologija, br. 20-21, 1992.-1993., str. 585-93. 


\section{(c) (i) (9)}

Creative Commons Attribution-NonCommercial-NoDerivatives 4.0 International License 